\title{
Peranan Hukum Dalam Persepektif Filsafat Terhadap Pemberantasan Korupsi
}

\author{
Nofil Gusfira ${ }^{1}$, Abdul Hafiz ${ }^{2}$ \\ 1,2Institut Agama Islam Negeri Takengon, Indonesia \\ Email konfirmasi: novilbasogusfira@gmail.com
}

\begin{abstract}
ABSTRAK
Tindak pidana korupsi bukan saja dapat dilihat dari perspektif hukum pidana, melainkan dapat dikaji dari dimensi lain, misalnya perspektif legal policy (law making policy dan law enforcement policy), Hak Asasi Manusia (HAM) maupun Hukum Administrasi Negara. Tindak pidana korupsi merupakan salah satu bagian dari hukum pidana khusus. Apabila dijabarkan, tindak pidana korupsi mempunyai spesifikasi tertentu yang berbeda dengan hukum pidana umum, seperti penyimpangan hukum acara dan materi yang diatur dimaksudkan menekan seminimal mungkin terjadinya kebocoran serta penyimpangan terhadap keuangan dan perekonomian negara.
\end{abstract}

Kata Kunci : Filsafat, Korupsi, Hukum

\section{Pendahuluan}

Dikaji dari perspektif pembagian hukum berdasarkan isinya dikenal klasifikasi hukum publik dan hukum privat. Lebih lanjut, menurut doktrin, ketentuan hukum publik merupakan hukum yang mengatur kepentingan umum (algemene belangen) sedangkan ketentuan hukum privat mengatur kepentingan perorangan (bijzondere belangen). Apabila ditinjau dari aspek fungsinya maka salah satu ruang lingkup hukum publik adalah hukum pidana yang secara esensial dapat dibagi lagi menjadi hukum pidana materiil (materieel strafrecht) dan hukum pidana formal (formeel strafrecht/strafprocesrecht) (L.J. van Apeldoorn, 2005: 171).

Selanjutnya, ketentuan hukum pidana sesuai konteks di atas dapat diklasifikasikan menjadi hukum pidana umum (ius commune) dan hukum pidana khusus (ius singulare, ius speciale atau bijzonder strafrecht). Ketentuan hukum pidana umum dimaksudkan berlaku secara umum sebagaimana termaktub dalam Kitab Undang-Undang Hukum Pidana (KUHP), sedangkan hukum pidana khusus menurut W.P.J. Pompe, H.J.A. Nolte, Sudarto dan E.Y. Kanter diartikan ketentuan hukum pidana yang mengatur mengenai subyeknya dan perbuatan yang khusus (bijzonder lijkfeiten) (Lilik Mulyadi, 2007: 1).

Tindak pidana korupsi merupakan salah satu bagian dari hukum pidana khusus. Apabila dijabarkan, tindak pidana korupsi mempunyai spesifikasi tertentu yang berbeda dengan hukum pidana umum, seperti penyimpangan hukum acara 
dan materi yang diatur dimaksudkan menekan seminimal mungkin terjadinya kebocoran serta penyimpangan terhadap keuangan dan perekonomian negara. Konvensi Perserikatan Bangsa-Bangsa (PBB) Anti Korupsi 2003 (United Nations Convention Against Corruption (UNCAC), 2003) (Romli Atmasasmita, 2006: 1) mendiskripsikan masalah korupsi sudah merupakan ancaman serius terhadap stabilitas, keamanan masyarakat nasional dan internasional, telah melemahkan institusi, nilai-nilai demokrasi dan keadilan serta membahayakan pembangunan berkelanjutan maupun penegakan hukum.

Konvensi PBB Anti Korupsi 2003 yang telah diratifikasi dengan UndangUndang (UU) Nomor 7 Tahun 2006, menimbulkan implikasi karakteristik dan subtansi gabungan dua sistem hukum yaitu "Civil Law" dan "Common Law", sehingga akan berpengaruh kepada hukum positif yang mengatur tindak pidana korupsi di Indonesia. Romli Atmasasmita menyebutkan implikasi yuridis tersebut, bahwa: nampak adanya kriminalisasi perbuatan memperkaya diri sendiri (illicit enrichment) dimana ketentuan Pasal 20 (United Nations Convention Against Coruuption (UNCAC) 2003 menentukan, bahwa: ...each State Party shall consider adopting... to establish as a criminal offence, when committed intentionally, illicit enrichment, that is, a significant increase in the assets of a public official that he or she cannot reasonably explain in relation to his or her lawful income". ( Romli Atmasasmita, 2006, hlm. 9-10).

Selain itu, dikaji dari perspektif internasional pada dasarnya korupsi merupakan salah satu kejahatan dalam klasifikasi White Collar Crime dan mempunyai akibat kompleksitas serta menjadi atensi masyarakat internasional. Konggres PBB ke-8 mengenai "Prevention of Crime and Treatment of Offenders" yang mengesahkan resolusi "Corruption in Goverment" di Havana tahun 1990 merumuskan tentang akibat korupsi, berupa:

1. Korupsi dikalangan pejabat publik (corrupt activities of public official) (Barda Nawawi Arief, 1998: 69):

a. Dapat menghancurkan efektivitas potensial dari semua jenis program pemerintah ("can destroy the potential effectiveeness of all types of govermental programmes")

b. Dapat menghambat pembangunan ("hinder development").

c. Menimbulkan korban individual kelompok masyarakat ("victimize individuals and groups").

2. Ada keterkaitan erat antara korupsi dengan berbagai bentuk kejahatan ekonomi, kejahatan terorganisasi dan pencucian uang haram.

Asumsi konteks tersebut di atas dapat ditarik suatu konklusi dasar tindak pidana korupsi bersifat sistemik, terorganisasi, transnasional dan multidimensional dalam arti berkorelasi dengan aspek sistem, yuridis, sosiologis, budaya, ekonomi antar negara dan lain sebagainya (Romli Atmasasmita, 2006: 1). 
Oleh karena itu, tindak pidana korupsi bukan saja dapat dilihat dari perspektif hukum pidana, melainkan dapat dikaji dari dimensi lain, misalnya perspektif legal policy (law making policy dan law enforcement policy), Hak Asasi Manusia (HAM) maupun Hukum Administrasi Negara. Selintas, khusus dari perspektif Hukum Administrasi Negara ada korelasi erat antara tindak pidana korupsi dengan produk legislasi yang bersifat Administrative Penal Law (Muladi, 2002: 40).

Berbicara filsafat, kita seakan berada pada ranah yang sangat abstrak, dan filsafat hukum merupakan cabang dari filsafat, filsafat hukum mempunyai fungsi yang strategis dalam pembentukan hukum di Indonesia, termasuk didalamnya peranan hukum didalam pemberantasan korupsi.

Sekedar menyinggung konsep dalam Islam, bahwa Islam menilai hukum tidak hanya berlaku di dunia saja, akan tetapi juga di akhirat, karena putusan kebenaran, atau ketetapan sanksi, disamping berhubungan dengan manusia secara langsung, juga berhubungan dengan Allah SWT, (Muchsin, 2006: 24) maka manusia disamping ia mengadopsi hukum-hukum yang langsung (baca; samawi dalam Islam) wahyu Tuhan yang berbentuk kitab suci, manusia dituntut untuk selalu mencari formula kebenaran yang berserakan dalam kehidupan masyarakat, manusia akan melihat dari kenyataan empiris sebagai bekal mengkaji secara mendalam, memberikan makna filosofis dengan mengetahui hakikat kebenaran yang hakiki.

Kaitannya dengan pembentukan hukum di Indonesia, setidaknya kita sadar bahwa hukum di bentuk karena pertimbangan keadilan (gerechtigkeit) disamping sebagai kepastian hukum (rechtssicherheit) dan kemanfaatan (zweckmassigkeit) (Darji Darmodiharjo dan Shidarta, 2006: 154).

Keadilan ini berkaitan dengan pendistribusian hak dan kewajiban, diantara sekian hak yang dimiliki manusia terdapat hak yang bersifat mendasar yang merupakan anugerah alamiah langsung dari Allah SWT, yaitu hak asasi manusia atau hak kodrati manusia, semua manusia tanpa pembedaan ras, suku, bangsa, agama, berhak mendapatkan keadilan, maka di Indonesia yang notabene adalah negara yang sangat heterogen tampaknya dalam membentuk formulasi hukum positif agak berbeda dengan negara-negara yang kulturnya homogen, sangatlah penting kiranya sebelum membentuk suatu hukum yang akan mengatur perjalanan masyarakat, haruslah digali tentang filsafat hukum secara lebih komprehensif yang akan mewujudkan keadilan yang nyata bagi seluruh golongan, suku, ras, agama yang ada di Indonesia, penulis tertarik dengan argumen Bismar Siregar bahwa ia pernah mengatakan "bila untuk menegakkan keadilan saya korbankan kepastian hukum, akan saya korbankan hukum itu, hukum hanya sarana, sedangkan tujuan akhirnya adalah keadilan", lalu bagaimana sebenarnya peranan hukum dalam mencerminkan keadilan yang didambakan, untuk itulah penulis tertarik untuk 
mencoba mendudukkan filsafat hukum sebagai Starting Point peranan hukum dalam pemberantasan korupsi di Indonesia.

\section{Metode Penelitian}

Penulisan ini menggunakan penelitian hukum normatif atau perpustakaan yang merupakan penelitian yang mengkaji studi dokumen. Penelitian jenis normatif ini menggunakan analisis kualitatif yakni dengan menjelaskan data yang ada dengan kata-kata atau pernyataan bukan dengan angka-angka. Dalam penelitian ini penulis memperoleh sumber data dari bahan sumber data primer dan sumber data sekunder. Teknik pengambilan data ini dengan membaca buku-buku/ jurnal maupun situs internet yang berkaitan dengan tema penulisan ini. Analisis data yang digunakan penelitian ini adalah teknik analisis kualitatif.

\section{Pembahasan/hasil}

Salah satu kelebihan manusia yang tidak dimiliki oleh makhluk - makhluk tuhan lainnya adalah keingintahuannya yang sangat dalam terhadap segala sesuatu dialam semesta ini. Sesuatu yang diketahui oleh manusia itu disebut pengetahuan (Darji Darmodiharjo dan Shidarta, 2006: 1).

Ditilik dari sumber perolehannya, pengetahuan itu dapat dibedakan dalam beberapa maacam. Apabila pengetahuan itu diperoleh manusia melalui indera manusia, disebut pengetahuan indera (pengetahuan biasa). Jika pengetahuan tersebut diperoleh mengikuti metode dan system tertentu serta bersifat universal, disebutlah pengetahuan itu sebagai pengetahuan ilmiah. Selanjutnya, apabila pengetahuan itu diperoleh melalui perenungan yang sedalam-dalamnya (kontemplasi) sampai kepada hakikatnya, muncullah pengetahuan filsafat. Jika pengetahuan itu bersumber dari keyakinan terhadap ajaran suatu agama, pengetahuan semacam ini disebut pengetahuan agama (Darji Darmodiharjo dan Shidarta, 2006: 1).

Pengetahuan manusia, terlepas dari mana sumber perolehannya sesungguhnya merupakan jawaban terhadap pertanyaan-pertanyaan manusia, termasuk di dalam kehidupan berbangsa dan bernegara, dimana dalam menjalankan kehidupan bernegara tersebut sering dibawa oleh pengaruh yang tidak baik sehingga menyimpang dari kebenaran secara universal. Berbagai macam pengaruh yang bisa membawa suatu Negara kepada yang tidak baik adalah adanya pengaruh yang dinamakan dengan korupsi.

Korupsi telah menjadi suatu sifat yang tidak bisa dikatakan sebagai perbuatan yang baik dari sudut pandang nilai-nilai kehidupan berbangsa dan bernegara secara utuh dimanapun. Korupsi telah membawa pengaruh terhadap moralitas kehidupan setiap individu, dan tindakan dari itu adalah setiap kita menginginkan adanya gerakan untuk kembali kepada moralitas yang baik. Timbulnya kesadaran moral untuk melawan korupsi diawali dengan kesadaran moral dan pendirian manusia 
terhadapnya. Jika dipandang dari sudut kesusilaan. Kesadaran itu adalah seperti "ein ruf aus mid und doch uber mich", seperti pangilan yang timbul dari aku akan tetapi mengatasi diriku. Hidup susila dan tiap-tiap perbuatan susila adalah jawaban yang tepat terhadap kesadaran itu dan sebaliknya hidup yang tidak susila dan tiap-tiap pelanggaran kesusilaan adalah menentang kesadaran tersebut (N. Drijarkara S.J, 1978: 12).

Kenyataan adanya perilaku korupsi yang diakui merupakan suatu perbuatan yang tidak baik telah menimbulkan perlawanan terhadap adanya kegiatan korupsi ini. Dalam hidup ini dijumpai adanya dua macam kenyataan. Pertama, kenyataan yang disepakati (agreed reality), yaitu segala sesuatu yang dianggap nyata karena kita bersepakat menetapkannya sebagai kenyataan; kenyataan yang dialami orang lain dan kita akui sebagai kenyataan. Kedua, kenyataan yang didasarkan atas pengalaman kita sendiri (experienced reality) (Juhaya S. Praja, 2002: 1). Kenyataan ini didapati didalam perilaku korupsi, baik kenyataan yang disepakati maupun kenyataan yang didasarkan kepada pengalaman diri sendiri.

Bila kita menghadap hukum, pertama-tama kita insyaf bahwa hukum harus dikaitkan dengan kehidupan sosial: "hukum adalah pertama-tama penataan hidup sosial" (E. Utrecht, 1995: 39). Perumusan ini masih sangat abstrak, akan tetapi justru karenanya meliputi macam-macam bentuk hukum.

Adanya berbagai jenis hukum, diantaranya diterangkan oleh tokoh positivisme, John Austin (1790-1859). Menurut Austin terdapat macam-macam hukum yakni (E. Utrecht, 1995: 40-41):

1. Hukum Allah, hukum ini lebih-lebih merupakan suatu moral hidup daripada hukum dalam arti yang sejati

2. Hukum Manusia, yakni segala peraturan yang dibuat oleh manusia sendiri

Filsafat hukum harus berikhtiar mencapai tujuannya untuk menguasai dengan mutlak kehidupan hukum. Harus dimulai dengan mencari dimana-mana adanya macam-macam bentuk penjelmaan hukum dan menetapkan tempatnya bentuk-bentuk tersebut dalam masyarakat (Soetiksno, 1984: 52).

\section{Peranan Hukum Dalam Perspektif Filsafat Terhadap Pemberantasan Korupsi Di Indonesia}

Fungsi Hukum (The Funcions of Law) menurut Sjachran Basah, hukum terutama dalam masyarakat Indonesia mempunyai panca fungsi, yaitu: 1). Direktif, 2). Integratif, 3). Stabilitatif, 4). Perfektif 5). Korektif. Dalam Implementasinya Hukum Dapat Berwujud: 1). Preventif 2). Represif dan 3). Rehabilitatif. Tujuan Hukum Menurut Teori Etis (Aristoteles) Hukum hanya semata-mata bertujuan untuk mewujudkan rasa keadilan, sedangkan keadilan dibedakan menjadi dua yaitu : 1).Keadilan komutatif, yang menyamakan prestasi dan kontra prestasi, dan yang ke 2). Keadilan Distributif, keadilan yang membutuhkan distribusi atau penghargaan. 
Di dalam filsafat dengan adanya fungsi hokum yang demikian maka ini merupakan termasuk kedalam cita-cita filsafat. Filsafat mengharapkan dijalankannya kebenaran itu secara hakiki yaitu adanya keadilan sebenarnya yang berdasarkan nilai-nilai nurani yang sehat dengan didukung oleh fakta-fakta secara materil.

Bagi filsafat, kajian terhadap hokum bukan merupakan sekedar menilai teksteks yang ada didalam suatu peraturan hokum, tetapi lebih dari itu adalah bagaimana hokum itu terlaksana dengan baik sehingga keberlakuan hokum berjalan secara baik. Keberlakuan hokum yang baik itu adalah dengan terpenuhinya aspek filosofis yaitu apa yang dicita-citakan secara bersama dan diaplikasikan dalam kehidupan sehari-hari, kemudian terpenuhinya aspek sosiologis yaitu diterimanya hokum secara totalitas oleg seluruh masyarakat tanpa adanya pengecualian dan ini ditaati oleh seluruh masyarakat, dan yang terkahir adalah adanya aspek yuridis yaitu filsafat mengaharapkan hokum yang diterapkan bagi seluruh masyarakat dibuat dengan cara -cara yang baik dan sesuai dengan prosedurnya yang berlaku.

Meneropong kepada filsafat maka inti yang dicari adalah pemberantasan terhadap korupsi yang efektif dan mencapai sasaran tanpa adanya dilukai salah satu pihak. Didalam pemberantasan korupsi maka pihak yang dapat melakukan pemberantasan korupsi adalah seluruh elemen masyarakat tanpa ada pengecualian. Seluruh elemen masyarakat ini bergerak secara katif untuk melakukan pengawasan terhadap individu lain terasuk kepada dirinya sehingga sifat atau keinginan untuk melakukan korupsi dapat terhindar dan tidak terjadi inilah yang disebut dengan pengawasan melekat, setiap anggota masyarakat diberi pendidikan dan pemahaman bahwa ini merupakan sifat yang tidak baik, namun ketika hali ini terjadi maka yang berperanan adalah para penegak hokum yang diakui oleh Negara yaitu seperti adanya lembag komisi pemberantasan korupsi yang independent dan terlepas dari campur pihak manapun.

Para pihak yang telah diberi kewenangan untuk melakukan saling menegur atau pengawasan terhadap individu lain ini, maka hokum dalam kacamata filsafat adalah sebagai penjaga gawang atau katalisator terhadap kemungkinan terjadinya korupsi, sehingga dengan katalisator ini maka keinginan untuk melakukan perbuatan korupsi dapat terhindar dari pelaku, dengan adanya hokum sebagai penjaga gawang ini akan meberikan batasan yang jelas apa yang dimaksud dengan korupsi itu dengan ancaman hukuman yang sangat berat menurut nurani keadilan masyarakat Indonesia itu sendiri.

Adanya hokum sebagai katalisator ketika korupsi akan dilakukan maka ia akan berfungsi sebagai alat untuk mencegah secara preventif terhadap perilaku yang tidak baik atau perbuatan korupsi yang akan dilakukan dapat untuk tidak dilakukan, dan harapannya adalah terjadinya keinsyafan untuk tidak melakukan perbuatan korupsi tersebut. Ini secara preventif, kemudian ketika perbuatan korupsi itu elah dilakukan maka hokum akan berperan sebagai alat represif yaitu mencegah 
perbuatan korupsi itu meluas pelaksanaannya. Dan ini diperlukan peranan dari seluruh elemen masyarakat yang akan menghasilkan people power sebagai pengontrol langsung perbuatan korupsi.

Perlaksanaan peranan hokum peranan hokum dalam perspektif filsafat terhadap pemberantasan korupsi di Inodenesia pada akhirnya dapat dilaksanakan dengan jalan prinsip islah yang ada dalam agama Islam, pada prinsip ini seluruh manusia yang ada di Indonesia dianggap tidak pernah melakukan perbuatan korupsi, pada masa ini diberi juga kemudahan bagi para pelaku korupsi untuk melakukan upaya pengembalian uang atau hasil korupsi dengan menempatkan suatu tempat tertentu tanpa diketahui dan tanpa akan mendapatkan stigma apapun dari seluruh masyarakat.

Akhir dari pola ini adalah akan menghasilkan pola terakhir yaitu dengan adanya pola semut yaitu yang dilaksanakan seluruh masyarakat dan penegak hokum sehingga pengawasan melekat seperti apa yang disampaikan berjaan sebagaimana mestinya lalu diadakan stigma secara people power maka terciptalah masyarakat yang berkeadilan.

\section{KESIMPULAN}

Dalam Filsafat hukum dalam menyikapi masalah, kita diajak untuk berfikir kritis dan radikal, atau dalam artian kita diajak untuk memahami hukum tidak dalam arti hukum positif semata, karena jika kita hanya mempelajari arti hukum dalam arti positif semata, tidak akan mampu memanfaatkan dan mengembangkan hukum secara baik, jika demikian adanya ketika ia menjadi seorang pengadil (hakim) misalnya, ia hanya menjadi "corong undang-undang" belaka. Terkait itu penulis sepakat bahwa suatu masalah atau problem pasti dapat dicari apa sebenarnya analisis filsafat hukumnya yang tepat untuk diterapkan, dengan kita menganalisis secara rasional dan kemudian kita mempertanyakan jawaban secara terus menerus, yang jawaban itu tidak hanya dari masalah yang tampak, tetapi sudah pada tataran nilai dari gejala-gejala itu sendiri, maka analisis filsafati seperti inilah yang membantu kita untuk menentukan sikap secara bijaksana dalam menghadapi suatu masalah yang konkrit seperti adanya pemberantasam korupsi yang terjadi di Indonesia.

Supaya pemberantasn korupsi di Indonesia dapat berjalan sebagai mana mestinya maka kita secara bersama harus punya komitmen yang tinggi untuk membernatas dengan jalan pola Islah dan pola senut tersebut dilakukan secara adil..

\section{DAFTAR PUSTAKA}

A. Zainal Abidin Farid. 1995. Hukum Pidana I. Jakarta: Sinar Grafika.

Bambang Poernomo. 1982. Pandangan Terhadap Asas-Asas Umum Hukum Acara Pidana. Yogyakarta: Liberty. 
Barda Nawawi Arief. 1998. Beberapa Aspek Kebijakan Penegakan dan Pengembangan Hukum Pidana. Bandung: PT Citra Aditya Bakti.

2007. Masalah Penegakan Hukum dan Kebijakan Hukum Pidana Dalam Penanggulangan Kejahatan. Jakarta: Kencana Prenada Media Group.

Darji Darmodiharjo dan Shidarta. 2006. Pokok - Pokok Filsafat Hukum ; Apa dan Bagaimana Filsafat Hukum Indonesia. Jakarta: PT. Gramedia Pustaka Utama.

H. Muchsin. 2006. Ikhtisar Ilmu Hukum. Jakarta: IBLAM.

Indriyanto Seno Adjie. 2007. Kendala Administrative Penal Law Sebagai Tindak Pidana Korupsi \& Pencucian Uang. Jakarta: Paper.

J.M. van Bemmelen. 1979. Hukum Pidana 1 Hukum Pidana Material Bagian Umum. Bandung: Bina Cipta.

Jan Remmelink. 2003. Hukum Pidana Komentar Atas Pasal-Pasal Terpenting Dari Kitab Undang-Undang Hukum Pidana Belanda dan Padanannya Dalam Kitab UndangUndang Hukum Pidana Indonesia. Jakarta: PT Gramedia Pustaka Utama.

Juhaya S. Praja. 2002. Filsafat dan Metodologi Ilmu Dalam Islam dan Penerapannya di Indonesia. Jakarta: Teraju.

L.J. van Apeldoorn. 2005. Pengantar Ilmu Hukum. Jakarta: Pradnya Paramita.

Lilik Mulyadi. 2007. Asas Pembalikan Beban Pembuktian Terhadap Tindak Pidana Korupsi Dalam Sistem Hukum Pidana Indonesia Pasca Konvensi Perserikatan Bangsa-Bangsa Anti Korupsi 2003. Bandung: Alumni.

. 2007. Tindak Pidana Korupsi Di Indonesia (Normatif, Teoretis, Praktik dan Masalahnya). Bandung: Alumni.

Muchsin. 2006. Ikhtisar Filsafat Hukum. Jakarta: Penerbit Iblam.

Muladi. 2002. Kapita Selekta Sistem Peradilan Pidana. Semarang: Badan Penerbit Universitas Diponegoro

N. Drijarkara S.J. 1978. Percikan Filsafat. Jakarta: PT. Pembangunan.

Romli Atmasasmita. 2004. Sekitar Masalah Korupsi Aspek Nasional dan Aspek Internasional. Bandung: CV Mandar Maju. 2006. Desain Pemberantasan Korupsi. Jakarta: Paper. 2006. Indonesia Pasca Konvensi PBB Menentang Korupsi. Jakarta: Paper. 2006. Ratifikasi Konvensi Perserikatan Bangsa-Bangsa Menentang Korupsi Dan Implikasinya Terhadap Sistem Hukum Pidana Indonesia. Jakarta: Paper.

2006. Strategi dan Kebijakan Hukum Dalam Pemberantasan Korupsi Melawan Kejahatan Korporasi di Indonesia: Membentuk Ius Constituendum Pasca Ratifikasi Konvensi PBB Menentang Korupsi Tahun 2003. Jakarta: Paper.

- 2006. Strategi Dan Kebijakan Pemberantasan Korupsi Pasca Konvensi PBB Menentang Korupsi Tahun 2003: Melawan Kejahatan Korporasi. Jakarta: Paper 2006. Strategi Pemberantasan Korupsi Di Indonesia. Jakarta: Paper 2006. Strategi Pencegahan dan Pemberantasan Korupsi Di Sektor Swasta Dalam Lingkup Konvensi PBB Anti Korupsi 2003. Jakarta: Paper.

Satjipto Rahardjo. 2000. Ilmu Hukum. Bandung: PT Citra Aditya Bakti.

Soetiksno. 1984. Filsafat hukum 2. Jakarta: PT. Pradnya Paramita.

Theo Huijbers. 1995. Filsafat Hukum. Yogyakarta: Kanisius.

Yurisprudensi Mahkamah Agung Tahun 1970, dalam: Yurisprudensi Indonesia, Penerbit Mahkamah Agung RI, Jakarta, 1970, hlm. 143-146 dan 